\title{
Thermal studies on Arabic gum - carrageenan polysaccharides film
}

\author{
J.Jamaludin, F. Adam, R. Abdul Rasid, Z. Hassan
}

Faculty of Chemical Engineering \& Natural Resources, University Malaysia Pahang, Lebuhraya Tun Razak, 26300 Gambang, Pahang, Malaysia. Article Info: Submitted on March 20, 2017, Accepted on June 20, 2017.

\begin{abstract}
The main objective of this work is to develop film and study the thermal characteristics of polysaccharides films at various concentration of carrageenan in the mixture by calculating activation energy of polysaccharides films. There were four (4) film samples of two polysaccharides combination; arabic gum (AG) and carrageenan (C) with different formulations; sample A, sample B, sample C and sample D prepared. Sample A film is the control sample that contained only arabic gum and distilled water (DI) with $40 \%$ weight arabic gum per volume DI water (w/v\%). Meanwhile for sample B and C were prepared with concentration $40 \mathrm{w} / \mathrm{v} \%$ of Arabic gum and two differents of carrageenan concentrations; $1 \mathrm{w} / \mathrm{v} \%$ and $10 \mathrm{w} / \mathrm{v} \%$ respectively. Polyethylene glycol 400 (PEG 400) as a plasticiser was added into sample D film. The sample films were thermally characterized using differential scanning calorimetry (DSC) and thermogravimetric analysis (TGA) under nitrogen atmosphere. The major thermal transitions as well as, activation energies of the major decomposition stages were determined. Sample A and B films exhibited the highest $(112.43 \mathrm{~kJ} / \mathrm{mol})$ and the lowest $(102.89 \mathrm{~kJ} / \mathrm{mol})$ activation energy of thermal decomposition, respectively. The activation energies were lower at larger amounts of sulfate groups from carrageenan on the degradation reactions. The DSC trend for all samples shows two (2) major intense peaks recorded in the DSC thermograms; an endothermic transition at temperature around $100{ }^{\circ} \mathrm{C}$ and followed by an exothermic transition at temperature around $300{ }^{\circ} \mathrm{C}$. The endothermic transition is due to the heat absorption for dehydration of water, $\mathrm{H}_{2} \mathrm{O}$ and the decomposition of samples process. Meanwhile, the exothermic transition is caused by the formation of $\mathrm{H}_{2} \mathrm{O}, \mathrm{CO}$ and $\mathrm{CH}_{4}$ in polysaccharide film from dehydration, depolymerisation and decomposition at the high-temperature stages.
\end{abstract}

Keywords: Polysaccharide; Activation energy; Differential scanning calorimetry; Thermogravimetric analysis.

\section{Introduction}

Most of polysaccharide source comes from plant which can be used in a number of applications due to their high capacity to absorb water and behave like hydrogels. ${ }^{1}$ Their polysaccharides structure molecule can be in linear or branches that corresponding changes on their physical properties as its water solubility, viscosity, and gelling behavior. ${ }^{2}$ The polysaccharides film has potential in food and pharmaceutical industries as alternative material for edible film and hard capsule application due to the increased of the demand of halal products $s$ to avoid the prohibited gelatin material. ${ }^{3}$ Therefore, two common polysaccharides; arabic gum and carrageenan which are widely used in as approved main ingredient or additives in food industries due to their unique properties has been selected in this study. ${ }^{4,5}$ Arabic gum is an exudate tree gum that functioned as emulsifier agent in medicines or drink syrup because it is extremely soluble in water up to $50 \%$ concentration. ${ }^{6}$ Meanwhile, carrageenan is a seaweed extract that can be diluted in DI water to produce a very viscous solution at low concentration. ${ }^{7}$
To develop film from a combination of more polysaccharides suitable with their end product purpose, there is a need to study their thermal stability and degradation pattern. The highest activation energy, $E_{a}$ is an indicator the higher thermal stability. For example, Barreto et al. has reported the higher thermal stability with the high values of $E_{a}$ and above than 100 $\mathrm{kJ} / \mathrm{mol}$ was observed for the synthetic polymers film in the comparison to biopolymers films. ${ }^{8}$ In addition, the activation energy value can help to calculate other parameters such as sample life time prediction. ${ }^{9}$ However, the activation energy alone cannot provide an integral prediction or modeling for thermal decomposition process without the pre-exponential factor and reaction model. ${ }^{10}$

There were several research studies has been conducted on thermal characteristic and calculation activation energy $\left(E_{a}\right)$ by using Broido model corresponding to TGA data. Based on previous studies, the similar trend of both natural and modified film TGA curves which at initial stage, the minimum mass loss percentage around $5-10 \%$ at temperature $100{ }^{\circ} \mathrm{C}$ and followed the polysaccharides 


\section{Chemical Engineering Research Bulletin 19(2017) 80-86}

decomposed rapidly started from $200{ }^{\circ} \mathrm{C}$ and completed at $400{ }^{\circ} \mathrm{C}$ with total mass loss percentage, $50 \%$ due to moisture desorption and polysaccharides degradation respectively. ${ }^{11-14}$ It was found that activation energy on arabic gum in range $122 \mathrm{~kJ} / \mathrm{mol}$ to $155 \mathrm{~kJ} / \mathrm{mol}^{11,12}$ The various of $E_{a}$ is influenced by the origin or species of arabic gum; A. senegal and $A$. seyal which is $E_{a}$ of $A$. seyal higher than A.senegal due to the larger of molecule weight of A.seyal; $770000 \mathrm{~g} / \mathrm{mol} .{ }^{11}$ Thermal behavior was influenced by the structure and functional group different of polysaccharides. The $E_{a}$ value of natural hydrogel or film will be increased or reduced when the natural hydrogel that has been modified by adding other polysaccharide in formulation development caused the changes of the natural molecule structure film. ${ }^{13,14}$ For example, the activation energy were reduced or lower due to sulfate group present. ${ }^{15}$ The lowest activation energy exhibited a fast degradation to yield very low char residue at $600{ }^{\circ} \mathrm{C} .{ }^{12}$ Table 1 summaries the activation energy of polysaccharide by some researchers using Broido method.

Table 1: Activation energy of various polysaccharides

\begin{tabular}{|c|c|c|}
\hline References & Polysaccharides & $\begin{array}{c}\text { Activation } \\
\text { Energy, } E_{a} \\
(\mathrm{~kJ} / \mathrm{mol})\end{array}$ \\
\hline $\begin{array}{l}\text { Zohuriaan } \\
\text { et al. } \\
(2004)^{12}\end{array}$ & $\begin{array}{l}\text { Arabic gum } \\
\text { Chitosan } \\
\text { Tragacanth } \\
\text { Xanthan gum } \\
\text { Sodium alginate } \\
\text { Sodium carboxymethyl } \\
\text { cellulose } \\
\text { Hydroxyethyl cellulose } \\
\text { Methyl cellulose }\end{array}$ & $\begin{array}{l}122 \\
219 \\
258 \\
179 \\
188 \\
230 \\
\\
121 \\
232\end{array}$ \\
\hline $\begin{array}{l}\text { Maciel et al. } \\
(2005)^{13}\end{array}$ & $\begin{array}{l}\text { Chitosan } \\
\text { Carboxymethyl } \\
\text { cashew gum } \\
\text { Polyelectrolyte } \\
\text { complex }\end{array}$ & $\begin{array}{c}80 \\
78.6 \\
19.0-36.2\end{array}$ \\
\hline $\begin{array}{l}\text { Cozic et al. } \\
(2009)^{11}\end{array}$ & $\begin{array}{l}\text { Arabic gum } \\
\text { (A. senegal) } \\
\text { Arabic gum } \\
\text { (A. seyal) }\end{array}$ & $\begin{array}{l}125 \\
155\end{array}$ \\
\hline $\begin{array}{l}\text { Iqbal et al. } \\
(2011)^{14}\end{array}$ & $\begin{array}{l}\text { Natural hydrogel: } \\
\text { Plantago ovata (PO), } \\
\text { Salvia aegyptiaca } \\
\text { (SA), Ocimum } \\
\text { basilicum (OB) and } \\
\text { Mimosa pudica (MP). } \\
\text { Modified hydrogel }\end{array}$ & $104.2-144.1$ \\
\hline
\end{tabular}

However, there are no study conducted to calculate activation energy of carrageenan or combination with others polysaccharides. Therefore, the main objective of the present study was to evaluate thermal degradation of arabic gum films with two concentrations of carrageenan in film formulations; $1 \%$ and $10 \%$ of composition total weight.

\section{Materials and Methods}

Arabic gum powder was supplied by Texture Innovation Centre (TIC Gums), USA which imported it from Africa. Its molecular weight is between $2.5 \times 10^{5}$ and $1 \times 10^{6} \mathrm{~g} / \mathrm{mol}$, which contains a small proportion of protein content $(2 \%)$ and has been classified as an arabinogalactan - protein complex. Total heavy metal elements content test including arsenic, lead, cadmium, mercury and chromium in arabic gum was less than 40 ppm that according to Indian Pharmacopeia. ${ }^{6}$ It was proved that arabic gum is non-toxic material and safe to be consumed by human. Carrageenan type kappacarrageenan (semi-refined) was origin from Sabah, Malaysia. Meanwhile, the plasticiser, PEG 400 was supplied by supplier, Sigma Aldrich. Arabic gum structure is a long chain with more than one different repeating monosaccharide units, complex and illknown ${ }^{16}$ that composes of galactose (Galp), arabinose (Araf), rhamnose (Rhap) and uronic acid (UA) ${ }^{17}$ with the red highlighted backbone of arabic gum structures. Kappa-carrageenan is one of carrageenan type from a red algae extract with a sulfate group (red circle) in its monosaccharide. Both of structure polysaccharides are shown in Figure 1.

\section{Preparation of polysaccharide films}

For formulation film $\mathrm{A}$ as a control sample, the 40 gram arabic gum was added in a beaker with $100 \mathrm{ml}$ distilled water and homogenised by using the magnetic stirrer on a hot plate (Thermo Scientific) for three (3) hours at temperature $60{ }^{\circ} \mathrm{C}$ until the homogenous and viscous solution obtained. After the stirring process, 50 $\mathrm{ml}$ of the solution was poured into polyethylene plate and the film was dried overnight at room temperature. The preparation method was repeated for film B, C and D. To prepare film B and C, two different concentrations of carrageenan solution; $1 \mathrm{w} / \mathrm{v} \%$ and 10 w/v\% was added into two beakers that contained 40 w/v\% of arabic gum solution in two (2) beakers separately. For film D preparation, 1.5ml PEG 400 was added in a beaker with $40 \mathrm{w} / \mathrm{v} \%$ arabic gum and $10 \mathrm{w} / \mathrm{v} \%$ carrageenan solution. The dried films were peeled from the plate, kept all films into four (4) sealed plastic bag separately and placed in a desiccator until required for characterization analysis such as Differential Scanning Calorimeter (DSC) and Thermogravimetric Analysis (TGA). 


\section{Chemical Engineering Research Bulletin 19(2017) 80-86}

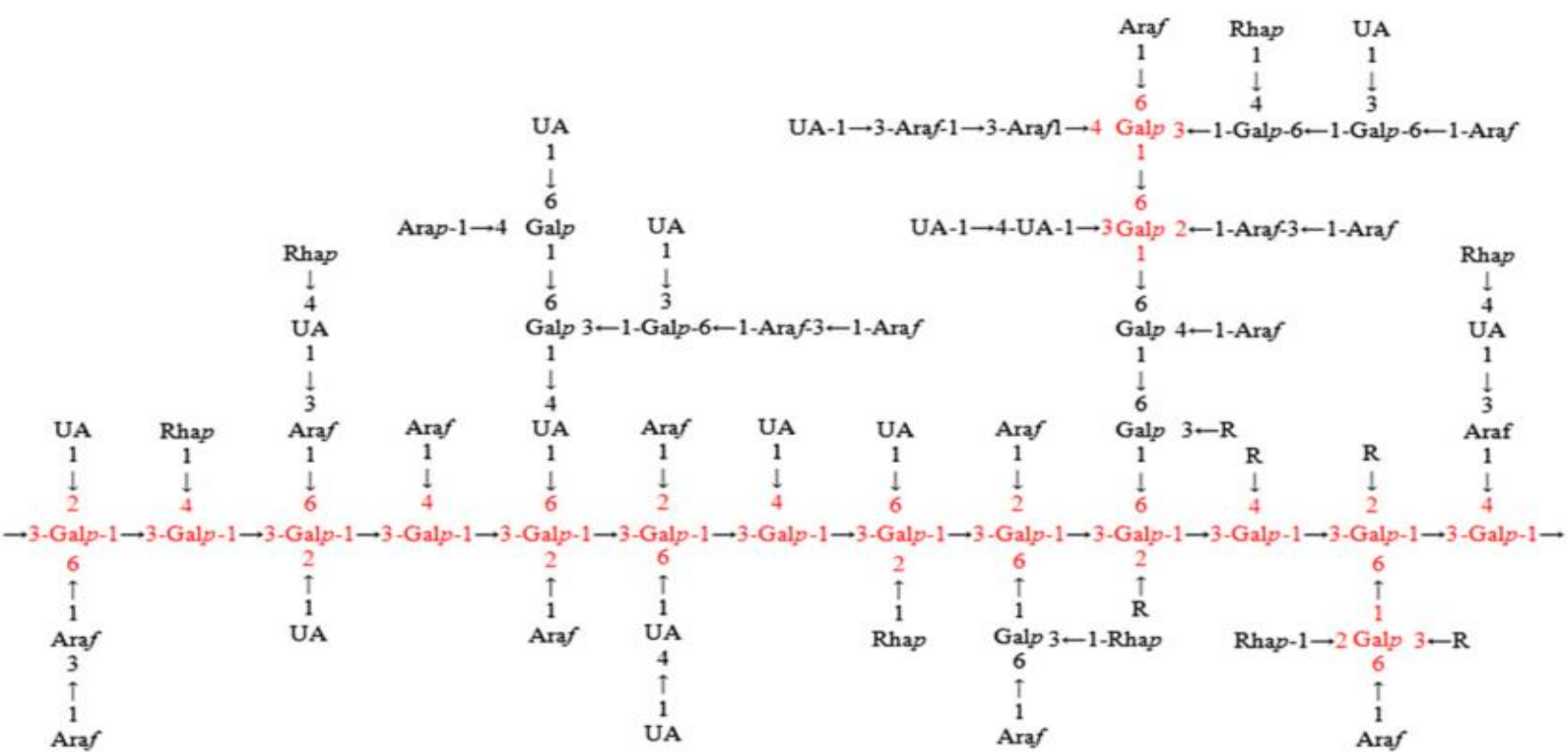

A

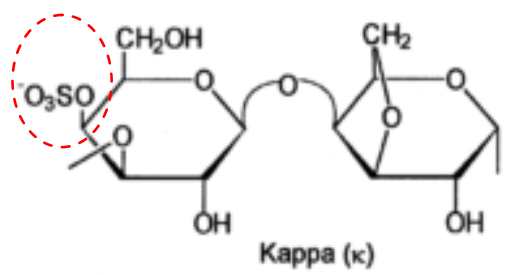

B

Figure 1: a) Arabic gum molecule structure ${ }^{18}$ and b) Kappa-carrageenan molecule structure ${ }^{19}$

Table 2 is the summary of the formulation for each film.

Table 2: Formulation of polysaccharides films

\begin{tabular}{|l|l|l|}
\hline Sample Name & Sample Code & $\begin{array}{l}\text { Formulation } \\
\text { (w/v\%) }\end{array}$ \\
\hline A & AG4 & $\begin{array}{l}40 \% \text { arabic gum } \\
40 \% \text { arabic gum, } \\
1 \% \text { carrageenan }\end{array}$ \\
\hline B & AG4C0.1 & $\begin{array}{l}40 \% \text { arabic gum, } \\
10 \% \text { carrageenan }\end{array}$ \\
\hline C & AG4C1 & $\begin{array}{l}40 \% \text { Arabic gum, } \\
10 \% \text { carrageenan } \\
1 \text { ml PEG 400 }\end{array}$ \\
\hline D & AG4C1P & \\
\hline
\end{tabular}

\section{Thermal analysis}

\section{Differential scanning calorimetry (DSC)}

DSC has been used to study thermal transitions occurring in the course of heating under an inert atmosphere by using a TA Instruments, model Q 1000 series. A sample weighing between 3-5 mg was sealed in an aluminium pan and heated from current temperature to $400{ }^{\circ} \mathrm{C}$ at a rate $10{ }^{\circ} \mathrm{C} / \mathrm{min}$, in nitrogen atmosphere.

\section{Thermogravimetry analysis (TGA)}

TGA is a simple and accurate method for studying the decomposition pattern and the thermal characterisation of polysaccharides films by using TA instrument; model Q 500 series with the heating rate of TGA was $10{ }^{\circ} \mathrm{C} / \mathrm{min}$ for a temperature range up $600{ }^{\circ} \mathrm{C}$. Nitrogen gas as the purge gas in rate $60 \mathrm{ml} / \mathrm{min}$. Measurements were run in triplets and average values were recorded.

\section{Calculation of activation energy}

By using thermal analysis techniques including TGA and DSC, activation energy has been calculated. Activation energy is defined as a minimum energy that required to break the molecule bond among in the structure of material during thermal degradation. Calculation of activation energy based on the kinetic Arrhenius theory and TGA data. Activation energy 


\section{Chemical Engineering Research Bulletin 19(2017) 80-86}

$\left(E_{a}\right)$ for a major stage of decomposition was $\ln [\ln 1(1-\alpha)]=-\left(\frac{E a}{R T}\right)+$ Constant (1) Eq. 1

$\ln [\ln 1(1-\alpha)]=\ln \ln (1 / y)$

$$
\left(\frac{E a}{R}\right)\left(\frac{1}{T}\right)=X\left[\frac{1000}{T}\right]
$$

Eq. 3

with gas constant; $\mathrm{R}=8.314 \mathrm{Jmol}^{-1} \mathrm{~K}^{-1}$

where $\alpha$ is the degree of conversion given by formulation; $\alpha=W_{\mathrm{e}} / W_{0} \cdot W_{\mathrm{e}}$ is the mass of polymer evolved as volatile fragments in gram and $W_{0}$ is the initial mass in gram, $E_{a}$ is the apparent activation energy in unit $\mathrm{Jmol}^{-1}$ and $\mathrm{R}$ is the gas constant. $\mathrm{T}$ is the temperature recorded on the thermogram. The slopes of $\ln \ln (1 / \mathrm{y})$ vs. $1 / \mathrm{T}$ were plotted by using TGA data and $E_{a}$ was calculated by using Eq. 3 .

\section{Results and Discussion}
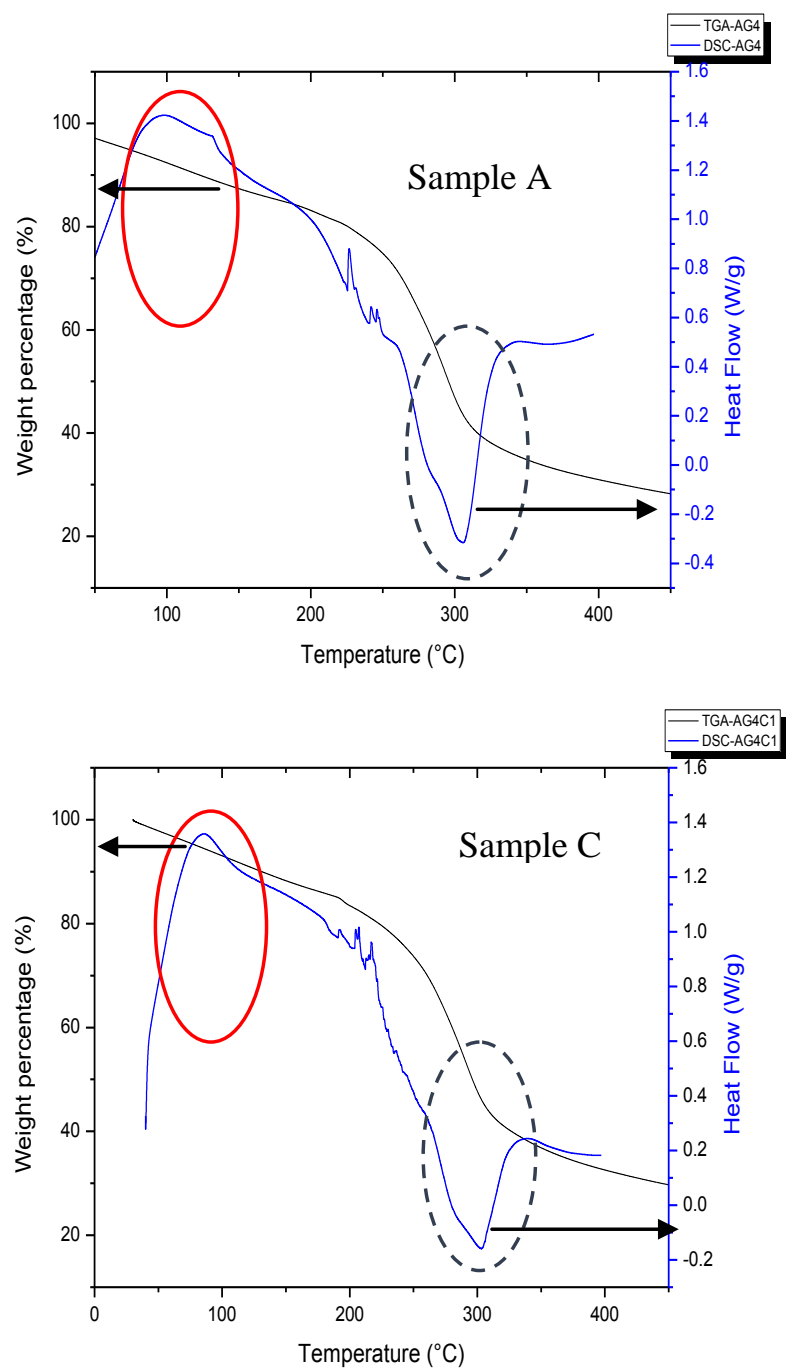

Notes:

Endothermic transition

Figure 2: TGA and DSC trend for sample A, B, C and D determined by Broido’s method using Eq. (1).

\section{Thermal analysis}

Figure 2 shows the combination of TGA curve and DSC Curves for each sample. Based on Figure 2, mostly DSC results show the enthalpy change during the heating of samples at high temperature. There are two (2) major intense peaks recorded in the DSC thermograms; an endothermic transition at temperature around $100{ }^{\circ} \mathrm{C}$ and followed by an exothermic transition at temperature around $300{ }^{\circ} \mathrm{C}$. The endothermic transition occurred due to the heat absorption for dehydration of water, $\mathrm{H}_{2} \mathrm{O}^{21}$ and the decomposition of samples. Meanwhile, the exothermic transition is caused by the formation of $\mathrm{H}_{2} \mathrm{O}, \mathrm{CO}$ and $\mathrm{CH}_{4}$ in polysaccharide film from dehydration, depolymerisation and decomposition in these high temperature stages ${ }^{12}$.
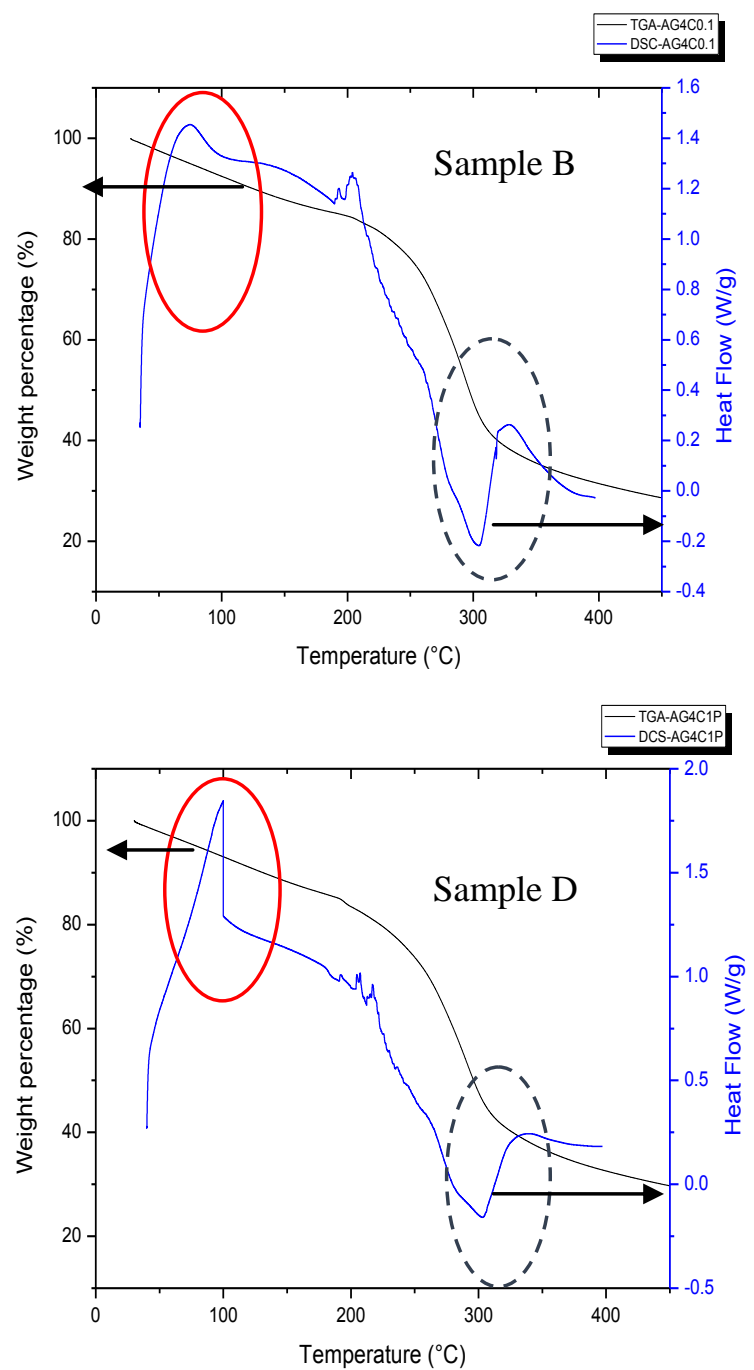

Exothermic transition 


\section{Chemical Engineering Research Bulletin 19(2017) 80-86}

However, because of the difference in structures and functional groups, the degradation routes or the resulting fragments were different. A polysaccharide like Arabic gum is comprised of carboxylate or carboxylic acid functional groups. Therefore, thermal transition of the carboxylate groups and evolution of $\mathrm{CO}_{2}$ from the corresponding carbohydrate backbone may be a probable mechanism for the thermal transitions. ${ }^{12}$

\section{TGA trend and activation energy calculation}

Based on the TGA graph (Figure 3), the trend of all polysaccharides films seem similar with double steps; water desorption stage and major decomposition stage. During initial phase at temperature below $100{ }^{\circ} \mathrm{C}$ (boiling point of water), about $10 \%$ mass loss of total weight percentage is due to water loss are observed as demonstrated by Mothé and Rao (2000) ${ }^{21}$, Zohuriaan and Shokrolahi (2004) ${ }^{12}$ and also Cozic et al. (2009) ${ }^{11}$. It is followed the second step, the polysaccharides film and found no drastic difference occurs between temperature $100{ }^{\circ} \mathrm{C}$ to $200{ }^{\circ} \mathrm{C}$ with the weight loss percentage; average $10 \%$. Above $200^{\circ} \mathrm{C}$, the trend rapidly decreased during the polysaccharide degradation process and finally reaching the constant mass of residue (23\%-26\%) is obtained at high temperature as reported by Cozic et al. (2009). ${ }^{11}$ Therefore activation energy for major decomposition between temperature; $200{ }^{\circ} \mathrm{C}$ to $400{ }^{\circ} \mathrm{C}$ were calculated by using Broido equation. The fast degradation of film was required low activation energy. ${ }^{12}$

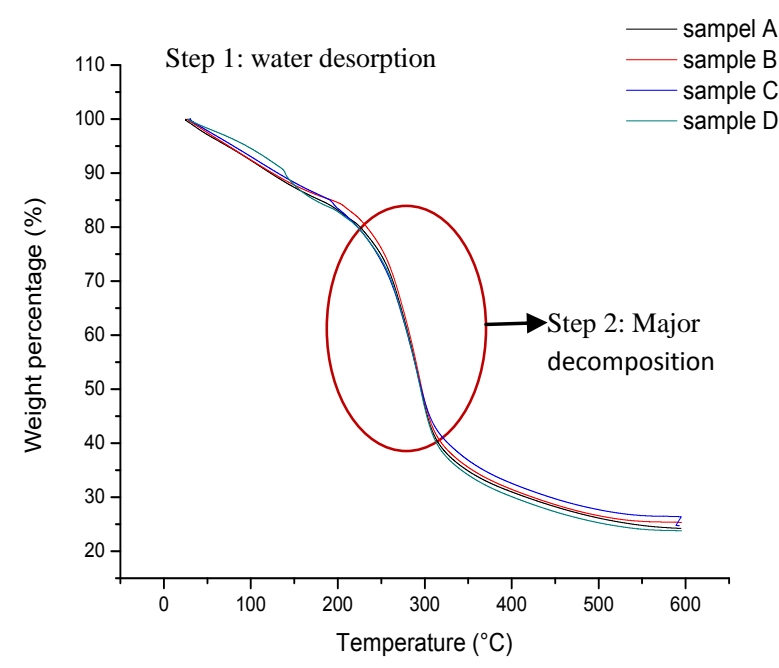

Figure 3: TGA trend for sample A, B, C and D.

Activation energies were calculated by using Eq. 1, Eq 2 and Eq.3. The slopes of In In (1/y) vs $1 / T$ were shown in Figure 4 and the activation energies for each major stage of decomposition were evaluated from the Broido slopes and summarized in Table 3 .

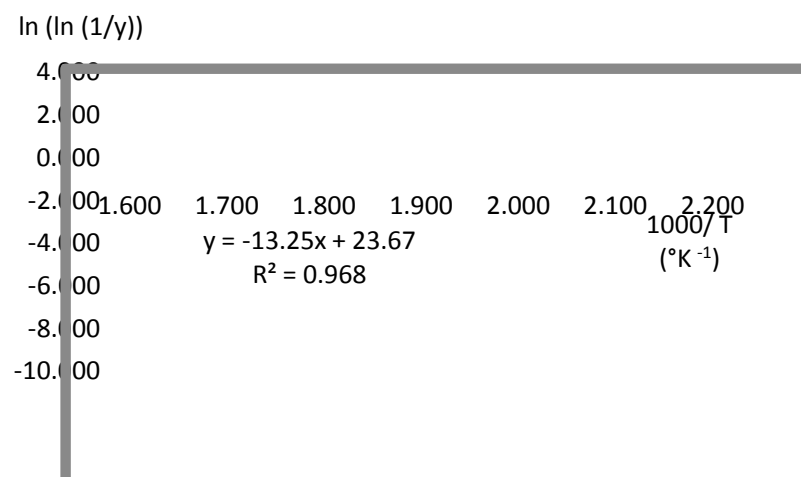

Sample A

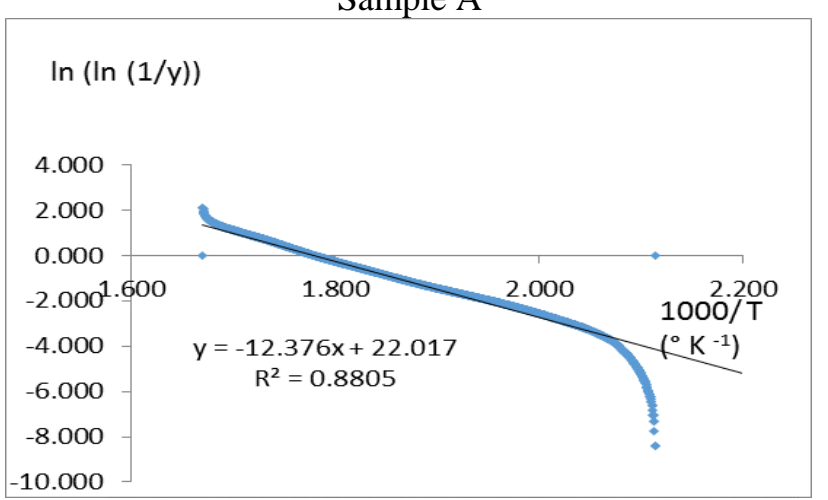

Sample B
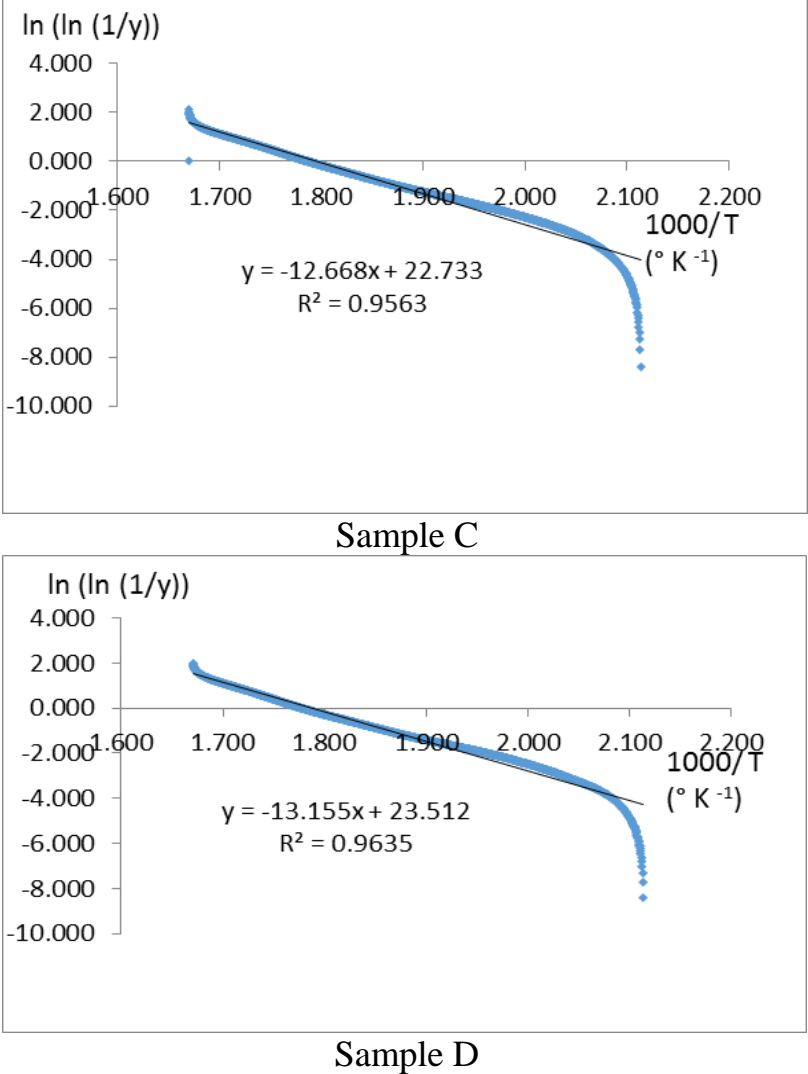

Figure 4: Broido plots for Sample A, B, C and D films. 


\section{Chemical Engineering Research Bulletin 19(2017) 80-86}

Table 3: Activation energy of polysaccharides film by using Broido calculation.

\begin{tabular}{|c|c|c|c|c|c|}
\hline Sample Name & Step & $\begin{array}{c}\text { Temperature range } \\
\left({ }^{\circ} \mathrm{C}\right)\end{array}$ & $\begin{array}{c}\text { Weight loss at step end } \\
(\%)\end{array}$ & $\begin{array}{c}\text { Residues at } \\
600{ }^{\circ} \mathrm{C}(\%)\end{array}$ & $\begin{array}{c}\text { Activation Energy, } \\
E_{a}(\mathrm{~kJ} / \mathrm{mol})\end{array}$ \\
\hline & 1 & $20-200$ & 16.87 & 24.21 & - \\
\hline & 2 & $200-600$ & 58.92 & & 112.44 \\
\hline B & 1 & $20-200$ & 15.46 & 25.33 & - \\
\hline C & 2 & $200-600$ & 59.21 & & 102.89 \\
\hline & 1 & $20-200$ & 16.55 & 24.74 & - \\
\hline D & 2 & $200-600$ & 58.71 & & 105.32 \\
\hline & 1 & $20-200$ & 17.14 & 23.79 & - \\
\hline
\end{tabular}

Based on the $E_{a}$ values, the highest activation energy of thermal decomposition of the polysaccharide films studies is sample A with value; $112.44 \mathrm{~kJ} / \mathrm{mol}$ followed by the sample D (mixture Arabic gum, carrageenan and plasticizer) and sample $\mathrm{C}$ (mixture arabic gum and $10 \%$ carrageenan) with value; 109.37 $\mathrm{kJ} / \mathrm{mol}$ and $105.32 \mathrm{~kJ} / \mathrm{mol}$ respectively. The lowest activation energy is sample B (mixture Arabic gum and $1 \%$ carrageenan).

Sample A film is the control sample which was formulated only arabic gum and distilled water instead of the other films contained arabic gum and carrageenan. The activation energy, $E_{a}$ of this sample is $112.44 \mathrm{~kJ} / \mathrm{mol}$, as compared to the previous study; $122 \mathrm{~kJ} / \mathrm{mol} .{ }^{12}$ Even, the sample A found the highest activation energy is consider good thermal stability, however sample A found brittle than other samples. Addition of carrageenan, the activation energy of polysaccharide films may reduce which corresponds to a study that conducted by Maren et al.(2004). ${ }^{15}$ In Table 3 , the activation energies in the addition of carrageenan into the film formulation of sample B, C and $\mathrm{D}$ are in the range $103-109 \mathrm{~kJ} / \mathrm{mol}$ become lower due to the presence of sulfate groups. ${ }^{15}$ A plasticizer is added to improve the brittleness problem in formulation of sample D and increased the value of $E_{a}$ of sample D.

Therefore, activation energy of natural polysaccharide film (arabic gum) reduced and the lower the activation energy means the fast degradation will occur during the polysaccharides decomposition. There are two factors which can influence the value of $E_{a}$; the condition of polysaccharides decomposition applied. $E_{a}$ is lower when thermal degradation occurs in air exposure compare to in nitrogen atmosphere. ${ }^{22}$ This study was conducted in inert atmosphere with Nitrogen gas only in TGA chamber. Another factor is the polysaccharides film structural variation. As for example, the $E_{a}$ of some natural hydrogel is shown in Table 1 found the changes of $E_{a}$ value due to the modification of polysaccharides formulation. ${ }^{16}$ Best of author's knowledge, there was no any study to calculate activation energy of arabic gum and carrageenan combination in film formulation.

\section{Conclusion}

Polysaccharides potential has grown fast in the various industries as food packaging film and empty capsule shell. The thermal characterisation study can give a better understanding on the decomposition of polysaccharide film and also the activation energy to reflect stability. Based on the $E_{a}$ values, the activation energy of thermal decomposition of the polysaccharide films studies is in the order of:

\section{Sample A > Sample D > Sample C > Sample B}

The finding of the activation energy on natural arabic gum film is $112.44 \mathrm{~kJ} / \mathrm{mol}$ which in the range 122 $\mathrm{kJ} / \mathrm{mol}$ to $155 \mathrm{~kJ} / \mathrm{mol}$ as reported by some researcher in the previous study. ${ }^{11,12}$ The activation energy in the addition of carrageenan (sample B, C and D) is lower than natural film due to the present of sulfate group from carrageenan. It has been proven that activation energy will increase or reduce when the natural film has been modified by adding other polysaccharide material in formulation film.

\section{Acknowledgement}

Support from the Department of Chemical and Natural Resources Engineering, University of Malaysia Pahang and e-science research grant from Ministry of Science and Technology, Malaysia are gratefully acknowledged. 


\section{Chemical Engineering Research Bulletin 19(2017) 80-86}

\section{References}

1. J. Akbar, M. S. Iqbal, S. Massey, and R. Masih, "Kinetics and mechanism of thermal degradation of pentose- and hexose-based carbohydrate polymers," Carbohydr. Polym., vol. 90, no. 3, pp. 1386-1393, 2012.

2. M. J. Gidley and J. S. G. Reid, Galactomannans and other cell wall storage polysaccharides in seeds. 2006.

3. A. A. Karim and R. Bhat, "Gelatin alternatives for the food industry: recent developments, challenges and prospects," Trends Food Sci. Technol., vol. 19, no. 12, pp. 644-656, 2008.

4. M. E. Osman, P. A. Williams, A. R. Menzies, and G. Phillips, "Characterization of Commercial Samples of Gum Arabic," pp. 71-77, 1993.

5. V. D. Prajapati, P. M. Maheriya, G. K. Jani, and H. K. Solanki, "Carrageenan: a natural seaweed polysaccharide and its applications.," Carbohydr. Polym., vol. 105, pp. 97-112, May 2014.

6. H. Panda, The Complete Book on Gums and Stabilizers for Food Industry. Delhi, India: ASIA PACIFIC BUSINESS PRESS Inc., 1 Oct 2010 480 pages, 2010.

7. H. D. Belitz, W. Grosch, and P. Schieberle., Food Chemistry, Third. Berlin, Germany: Springer Science \& Business Media, 21 Dec 2008 Technology \& Engineering, 2004.

8. P. L. M. Barreto, A. T. N. Pires, and V. Soldi, "Thermal degradation of edible films based on milk proteins and gelatin in inert atmosphere," Polym. Degrad. Stab., vol. 79, no. 1, pp. 147-152, 2003.

9. M. S. Iqbal, S. Massey, J. Akbar, C. M. Ashraf, and R. Masih, "Thermal analysis of some natural polysaccharide materials by isoconversional method," Food Chem., vol. 140, no. 1-2, pp. 178182, 2013.

10. M. Maciejewski, "Computational aspects of kinetic analysis. Part B: The ICTAC Kinetics Project $Đ$ the decomposition kinetics of calcium carbonate revisited, or some tips on survival in the kinetic minefield," Thermochim. Acta, vol. 355, no. 1-2, pp. 145-154, 2000.

11. C. Cozic, L. Picton, M.-R. Garda, F. Marlhoux, and D. Le Cerf, "Analysis of arabic gum: Study of degradation and water desorption processes," Food Hydrocoll., vol. 23, no. 7, pp. 1930-1934, Oct. 2009.

12. M. J. Zohuriaan and F. Shokrolahi, "Thermal studies on natural and modified gums," Polym. Test., vol. 23, no. 5, pp. 575-579, 2004.

13. J. S. Maciel, D. A. Silva, H. C. B. Paula, and R. C. M. De Paula, "EUROPEAN POLYMER Chitosan / carboxymethyl cashew gum polyelectrolyte complex: synthesis and thermal stability," vol. 41, pp. 2726-2733, 2005.

14. M. S. Iqbal, J. Akbar, S. Saghir, A. Karim, A. Koschella, T. Heinze, and M. Sher, "Thermal studies of plant carbohydrate polymer hydrogels," Carbohydr. Polym., vol. 86, no. 4, pp. 1775-1783, 2011.

15. M. Roman and W. T. Winter, "Effect of sulfate groups from sulfuric acid hydrolysis on the thermal degradation behavior of bacterial cellulose," Biomacromolecules, vol. 5, no. 5, pp. 1671-1677, 2004.

16. L. Lopez-Torrez, M. Nigen, P. Williams, T. Doco, and C. Sanchez, "Acacia senegal vs. Acacia seyal gums - Part 1: Composition and structure of hyperbranched plant exudates," Food Hydrocoll., vol. 51, pp. 41-53, 2015.

17. H. Espinosa-andrews, J. G. Ba, F. Cruz-sosa, and E. J. Vernon-carter, "Gum Arabic Chitosan Complex Coacervation," pp. 13131318, 2007.

18. S.-P. Nie, C. Wang, S. W. Cui, Q. Wang, M.-Y. Xie, and G. O. Phillips, "A further amendment to the classical core structure of gum arabic (Acacia senegal)," Food Hydrocoll., vol. 31, no. 1, pp. 42-48, May 2013.

19. R. Falshaw, H. J. Bixler, and K. Johndrob, "Structure and performance of commercial kappa-2 carrageenan extracts I. Structure analysis," Food Hydrocoll., vol. 15, no. 4-6, pp. 441-452, 2001.

20. K. A. Maleque, "Effects of Exothermic Endothermic Chemical Reactions with Arrhenius Activation Energy on MHD Free Convection and Mass Transfer Flow in Presence of Thermal Radiation,” J. Thermodyn., vol. 2013, 2013.

21. C. G. Mothé and M. a. Rao, "Thermal behavior of gum arabic in comparison with cashew gum," Thermochim. Acta, vol. 357-358, pp. 9-13, 2000.

22. P. Aggarwal, D. Dollimore, and K. Heon, "Comparative thermal analysis study of two biopolymers, starch and cellulose," J. Therm. Anal. Calorim., vol. 50, no. 1, pp. 7-17, 1997.

\section{Available online at http://www.banglajol.info/index.php/CERB}

Publisher: Department of Chemical Engineering, Bangladesh University of Engineering and Technology (BUET). Review \&Publication: A submitted original manuscript is taken into review only if the uniqueness is found to be more than $85 \%$ in plag-scanning and selected for publication by the complete acceptance from at least two reviewers out of three. Home Page: http://www.banglajol.info/index.php/CERB . Indexed by Chemical Abstract Service (CAS), CEABA-VtB, Google Scholar, Scopus and DOAJ. 